\title{
Old scissors to industrial automation: the impact of technologic evolution on worker's health
}

\author{
Rita de Cassia Clark Teodoroski ${ }^{\mathrm{a},{ }^{*}}$, Vanessa Mazzocchi Koppe ${ }^{\mathrm{b}}$ and Eugênio Andrés Díaz Merino ${ }^{\mathrm{c}}$ \\ ${ }^{a}$ Coordenação do Curso de Fisioterapia, Faculdade Estácio de Sá de Santa Catarina, SC, Brasil. \\ ${ }^{\mathrm{b}}$ Curso de Design de Moda da Faculdade Estácio de Sá de Santa Catarina, SC, Brasil. \\ cPrograma de Pós-Graduação em Engenharia de Produção e Núcleo de Gestão de Design, Universidade Federal \\ de Santa Catarina, SC, Brasil.
}

\begin{abstract}
To cut a fabric, the professional performs different jobs and among them stands out the cut. The scissors has been the instrument most used for this activity. Over the years, technology has been conquering its space in the textile industry. However, despite the industrial automation able to offer subsidies to answer employment market demands, without appropriate orientation, the worker is exposed to the risks inherent at the job. Ergonomics is a science that search to promote the comfort and well being in consonance with efficacy. Its goals are properly well defined and clearly guide the actions aimed at transforming the working conditions. This study aimed to analyze the activity of cut tissues with a machine by a seamstress and the implications on their body posture. The methodology used was the observation technique and application of the Protocol RULA, where the result obtained was the level 3 and score 5, confirming that "investigations and changes are required soon". Conclude that using the machine to tissue cut should be encouraged, but in conjunction with orientations for improving posture while handling it. It seeks to prevent dysfunction of the musculoskeletal system that prevents employees from performing their work tasks efficiently and productively.
\end{abstract}

Keywords: ergonomics, technology, RULA protocol, musculoskeletal disorders.

\section{Introduction}

Ergonomics is a science that seeks to promote the comfort and well being in line with the effectiveness and goals are well defined and clearly properly guide the actions which aim to transform work situations and target the ergonomist. The recommendations and the necessary adjustments in the adequacy of the task should be followed so that the operator provides a safe environment and at the same time, enabling the production and occurs as well, the perfect integration between man and his work.

Although there have been evidenced in this study, cognitive and organizational influences work activities significantly compromising the system man-task. In turn, we emphasized the physical aspects of ergonomics using anthropometry, which is a measurement method that allows measuring biomechanics of the human body for evaluation of its dimensions.

This study aimed to analyze the activity of cutting the fabric with a sewing machine and their implications on your posture.

\section{Theoretical foundation}

\subsection{Ergonomics}

Ergonomics as a science "[...] apply theories, principles, data and methods for projects that seek to optimize human well-being and overall system performance" [1]. The goals of ergonomics are well designed and properly guide the actions clearly aimed at trans-forming the work situations. The search for

\footnotetext{
*E-mail: rita.teodoroski@estacio.br. vanessamk@edu.etacio.br / merino@deps.ufsc.br
} 
comfort and well being in line with the effectiveness has been investigated to meet the constant action of the ergonomist in the daily world of work.

According to the Brazilian Ergonomics Association [2], areas of specialization are physical, cognitive and organizational. Each one has its own characteristics and its applicability has a comprehensive range, which makes the humans factors a science with an interdisciplinary character. In the website of that Association [2], you can view the peculiar description of each one, and described the Physical "is related to the characteristics of human anatomy, anthropometry, physiology and biomechanics in relation to physical activity" and turn Cognitive "refers to mental processes such as perception, memory, reasoning and motor response as affecting the interactions between humans and other elements of a system." Finally, the Organizational "concerns the optimization of systems technical partners, including organizational structures, policies and processes" [2].

\subsection{Automation in the textile industry}

"Increasingly the technology breaks the barrier of the improbable, the impossible and makes automation becomes constant in our production lines" [3]. The presence of automation in the global economy and human life is growing daily, and industrial automation (IA) today considered an essential tool for quality and productivity of companies [4].

"The main advance in this sector was the use of CAD / CAM technology, both in the design and drawing, as in the preparation and implementation of the cut tissue" [5]. The development of the court system is considered an important innovation based on microelectronic technology [6].

The same way, "instead of the old sewing machine manual at one point that revolutionized the means of production manufacturing, modeling and drawn on paper with the old manual cutting shears we are faced today with the sophistication of programmed machines that requires minimal knowledge of who operates the computer to make better use of the potential offered in CAD (Computer Aided Design) and CAM (Computer Aided Manufacturing), that optimize the processes of a workshop modeling, grading, marker and cut" [3].

With the purpose of increase the production and face the competition, companies have invested in new technologies in clothing, which are considered essential in terms of competitiveness [7,8]. "Observe the growth of competition and the entry of Brazilian products in international market increasingly demands speed and agility of enterprises, mainly in the fashion / clothing where style changes are regulars " [5].

The cut tissue is extremely importance in the process of making clothing and this can be accomplished in different ways [9] (FIGURE 1). The importance of this activity by describing that "after the definition of what is going to produce and what action to achieve, you should worry about the assembly of an industry that is vital to clothing industry: the court" [10].

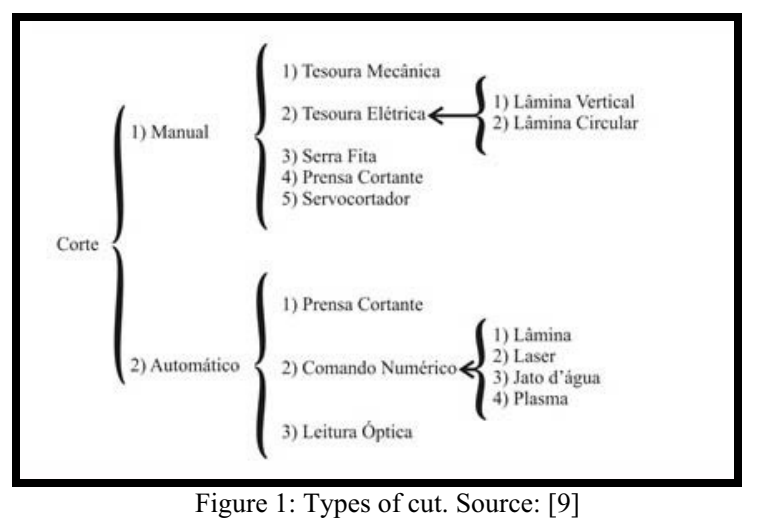

\subsection{Musculoskeletal disorders}

"Occupational diseases are caused by misuse and overuse of the system that brings together the bones, muscles, tendons and nerves, affecting mainly the upper limbs" [11]. These disorders began to appear with a higher incidence in the late 70', gaining strength in the $80^{\prime}$ and this decade, cases of tenosynovitis of typists have led unions data processing workers to fight for the recognition of occupational diseases and injuries [12]. However, "the development of most musculoskeletal disorders is multifactorial, unlike many occupational diseases that arise through exposure to a hazardous agent" [13].

Such disorders are characterized as "disorders neuro-musculo-tendinous origins of occupational affecting the upper limbs and neck, caused by repetitive use of the muscle group and forced movement or forced posture [12]. Pain is the main symptom and its location at some point usually starts gradually beginning to end underlying reaching all members [12]. For these authors, besides the pain, the worker complained of pain irradiated, paresthesia, swelling, stiffness, and limitation of movement amplitude, may occur associated with general symptoms such as an- 
xiety, irritability, mood swings and sleep, tension headache and fatigue.

\subsection{Protocol RULA}

"For an ergonomics intervention, we should perform the identification and quantification of risk factors present in the workplace" [14]. For this purpose, there are several assessment tools in physical ergonomics, each with its own specificity, each with its own specific character and purpose.

Protocol RULA, which means Rapid Upper Limb Assessment is a tool that was developed by Corlett and McAtamney in 1993 to investigate workers' exposure to risk factors associated with upper limb disorders related to work and promote a rapid assessment of the body $[15,16]$. "Is a flexible and fast which gives an assessment of biomechanical overload of the upper limbs and neck in an occupational task" [17].

It was developed in three phases, "the first was to create a system for recording work postures, followed by the determination of a scoring system, and the construction of a range of levels of action" [16].

In the spreadsheet analysis indicators are presented with diagrams of body postures and three scoring tables can indicate exposure to risk factors [16]. Based on the study of McAtamney and Corlett (1993), the author gives a schematic way the different factors investigated by the method of investigation RULA (FIGURE 2).

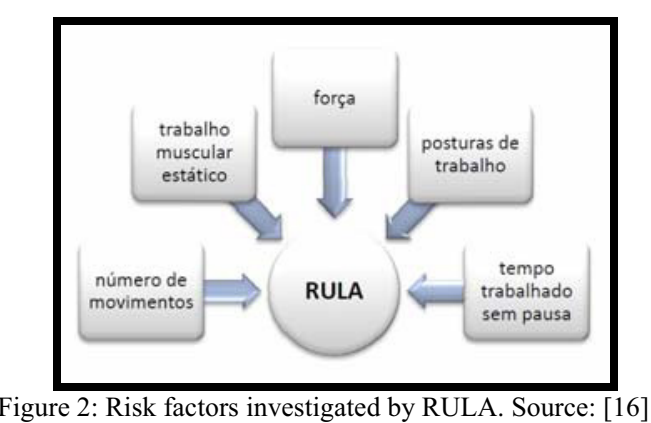

"Once users are familiar with RULA, they report that it is fast filling and easy to use" [16]. The method RULA is easily accessible, requires no special equipment and assessments can be conducted in enclosed workplaces without interrupting work [18].

\section{Methodology}

\subsection{Characteristics of research}

The research is characterized as descriptive case study. Descriptive research is interested in the discovery and observation of the phenomenon to seek their description, classification and interpretation so that the researcher know and interpret reality without interference or modification [19]. The case study's main characteristic is the deep and exhaustive study of one or more objects so that it will allow a more detailed knowledge [20].

Technique was used to record the observation data collected. This technique allows the "gathering information about reality through the senses (sight, hearing, touch, etc.)" [21].

\subsection{Casuistry}

The study was performed with a female employee for making a uniform that has the main task of cutting fabric.

\subsection{Measurement instruments}

For data collection instruments were used as a machine of Sony digital camcorder, model HDD DCR-SR82 and physical assessment worksheet method RULA [22].

\subsection{Procedures for data collection}

Data were collected according to procedures reported below:

- There was a previous contact with the manager's Clothing to obtain consent for the collection of research data;

- After authorization, the employee who performs the task of cutting allowed photographic records were made during their work activities;

- Anatomical points were marked on the upper right of the worker to facilitate the viewing angle of the movements during the work activity (FIGURES 3);

- Photographic records were made from scratch and fold the fabric, which precede the act of cutting (FIGURES 4 and 5);

- When you start cutting the fabric, photographic records were made in different postures for the selection and application of the RULA method (FIGURE $6)$. 


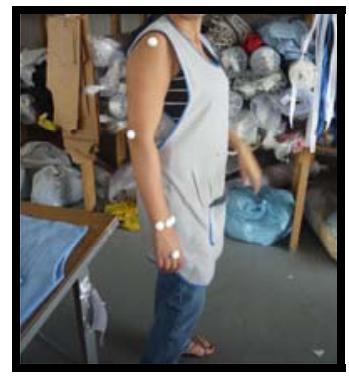

Figure 3: Anatomical points marked with styrofoam ball Source: Primary data (2011)

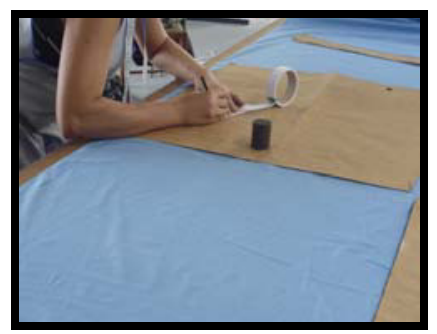

Figure 4: Risk of fabric from the mold Source: Primary data (2011)

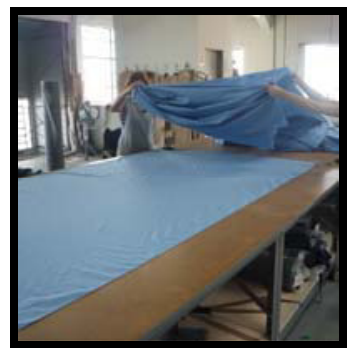

Figure 5: Enfesto of fabric before cutting Source: Primary data (2011)

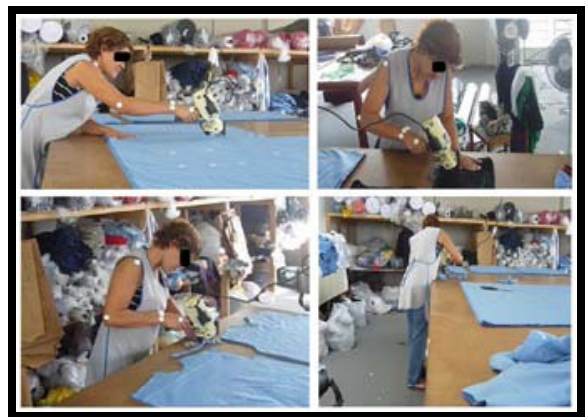

Figure 6: Cut fabric - situations I, II, III and IV Source: Primary data (2011)

\subsection{Processing of data}

The data were treated descriptively and for better visualization of results data were available in the form of photographs.

\section{Results and discussion}

\subsection{Selecting posture}

The definition of the work situation (FIGURE 7) for analysis and application of the RULA method was based on the stance adopted with the upper limb in extension mostly on the task, considering that the mobilization of the fabric should be avoided so as not to occur during cutting.

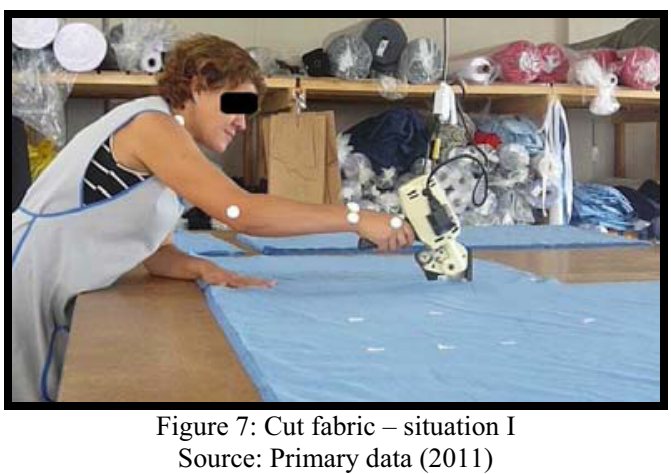

In this context, "depending on the type of study, selecting the posture can be made based on the duration of the procedure or the level of embarrassment shown, in other words, selecting the worst posture adopted by workers observed in that cycle" [18]. "The election of the method that best meet the needs of the analysis is defined by the characteristics of demand and a poor selection of a record can get results that do not reflect the physical work" [15]. However, although the RULA method has its applicability in the investigation of exposure risks to workers, "the authors of the tool reinforces the discourse that is an in-depth study of the situation needs to be conducted, the RULA should be used with one part of a large humans factors study, involving epidemiological investigations, physical, mental and organizational factors" [16].

\subsection{Application of the method RULA}

With the selection of posture analysis and after application of the RULA method, the end result obtained was the score at 3 and 5 (FIGURE 8), confirming that "investigations and changes are required soon". 


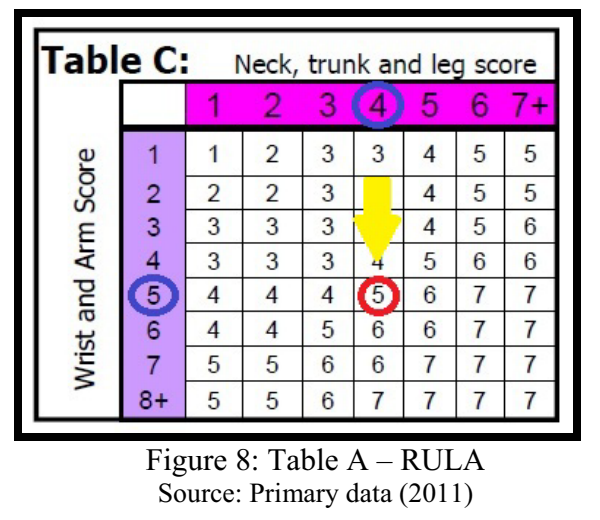

\subsection{Selecting posture}

It is important to note that "the recognition of risk factors in the work involves a set of procedures designed to define if exists or not a problem for the health of the worker" [23]. "What is RULA provides a guide that was developed to determine boundaries around extreme situations" [16]. Thus, to minimize the harmful effects of postures during work activities, the musculoskeletal system injuries can be better understood after an analysis of work postures [15]. "There is a certain kind of attitude that can be considered more appropriate for each type of task" [24] however, the author also describes that "if they are kept for a long time, can cause severe pain located in that set of muscles used in the conservation of these positions". "Postures require additional efforts and unexpected unbalanced and may reach the spine and the extremities superiorities" [25].

\section{Conclusion}

In an attempt to minimize the harmful effects of awkward postures at work, it is necessary to any study that can contribute to this end. In this case, RULA method was used in order to analyze the activity of cutting the fabric with a sewing machine and their implications on your posture.

Were able to observe that the activity of cutting machine has advantages and disadvantages. The advantages cited the ease of cutting machine by sliding over the fabric, increased production due to the cut simultaneously by several overlapping fabric and increase the effectiveness and direction for precision of the blade. In contrast, the disadvantage, it was evident that the poor body posture during the work activity is a risk factor capable of causing damage to workers' health. From the application of the RULA method, the position selected for analysis during the activity of cut tissue resulted in level 3 and 5 score thus confirming that "investigations and changes are required soon."

We conclude that the use of the machine to cut the fabric to be stimulated, but in conjunction with the guidance to improve posture while handling it. Thus, we seek to prevent the malfunctioning of the musculoskeletal system to prevent employees from performing their work tasks efficiently and productively.

For further studies, suggests that the ergonomic analysis has a scope in other areas of Ergonomics, focusing on the cognitive and organizational aspects, it is considered of extreme importance in understanding and transformation of work situations in reaching the goal of humans factors the balance between comfort and productivity.

\section{References}

[1] Definição internacional de ergonomia. Revista Brasileira de Ergonomia. ISSN 1519-7859. Disponível em: <http://www.acaoergonomica.ergonomia.ufrj.br/docs/defini cao.pdf> Acesso em: 22 mar. 2011.

[2] ABERGO. Associação Brasileira de Ergonomia. O que é ergonomia. Disponível em:

$<$ http://whttp://www.abergo.org.br/internas.php?pg=o que e ergonomiaww.abergo.org.br/estatuto.htm $>$ Acesso em: 25 abr. 2011

[3] Souza, W. G. de. Modelagem no design do vestuário. [2005?]. Disponível em: $<\underline{\text { http://fido.palermo.edu/servicios dyc/encuentro2007/02 a }}$ uspicios_publicaciones/actas diseno/articulos_pdf/A6045.p df $>$. Acesso em: 15 maio 2011 .

[4] Gutierrez, R. M. V.; Pan, S. S. K. Complexo eletrônico: automação do controle industrial. BNDES Setorial Automação Industrial. Rio de Janeiro, n. 28, p. 189-232, set. 2008. Disponível em: $<$ http://www.funcex.com.br/material/REDEMERCOSUL B IBLIOGRAFIA/biblioteca/ESTUDOS_BRASIL/BRA_141. pdf> Acesso em: 15 maio 2011.

[5] Dall'Onder, G. S. Análise projetual de metodologia para desenvolvimento de produto de moda na indústria do vestuário. 50 fl. 2007. Trabalho de Conclusão de Curso (Tecnólogo em Tecnologia do Vestuário) - União de Ensino do Sudoeste do Paraná, Dois Vizinhos, Paraná, 2007. Disponível em: $<\underline{\text { http://www.modavestuario.com/gracielascopeldallonder.pd }}$ f> Acesso em: 15 maio 2011.

[6] Lupatini, Márcio. Acumulação de capital e recriação de formas "pretéritas" de exploração: a particularidade da atividade de vestuário. In: Colóquio Internacional Max Engels, V da Unicamp, São Paulo, 2007. Disponível em: $<$ www.unicamp.br/cemarx/anais_v_coloquio arquivos/arqui vos/comunicacoes/gt3/sessao1/Marcio_Lupatini.pdf $>$. Acesso em: 25 set. 2011.

[7] Tavares, S. R. S. Modernização industrial em indústria de mão-de-obra: automação, informatização e inovações organizacionais na indústria do vestuário. Prod. [on line]. 
São Paulo, v. 1, n. 1, p. 41-48. jan./jun. 1990. ISSN 01036513. Disponível em:

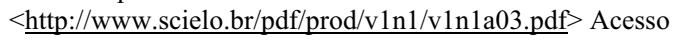
em: 15 maio 2011

[8] Silveira, Icléia. Usabilidade do vestuário: fatores técnico/funcionais. ano 1, n.1, jan./jul. 2008, p. 21-39, Modaplavra e-períodico [on line]. Disponível em: $<\underline{\text { http://argeu.ceart.udesc.br/modapalavra/edicao1/artigos/us }}$ abilidade iceliasilveira.pdf $>$ Acesso em: 15 maio 2011.

[9] Rosa, L. da. A indústria do vestuário da Grande Florianópolis: absorção de estudantes do curso superior de Moda da UDESC. 2005. 168 fl. Dissertação (Mestrado em Educação e Cultura) - Centro de Ciências da Educação da Universidade do Estado de Santa Catarina, Florianópolis, SC, 2005. Disponível em: $<\underline{\text { http://www.tede.udesc.br/tde arquivos/10/TDE-2005-10- }}$ 10T11:31:32Z-46/Publico/Lucas\%20da\%20Rosa.pdf $>$ Acesso em: 15 maio 2011.

[10] Romani, B. Estudo de caso no setor de corte em indústria de lingerie. 50 fl. 2004. Trabalho de Conclusão de Curso (Tecnólogo em Tecnologia do Vestuário) - União de Ensino do Sudoeste do Paraná, Dois Vizinhos, Paraná, 2004. Disponível em: $<$ http://www.modavestuario.com/bereniceromani.pdf $>$ Acesso em: 15 maio 2011.

[11] Ragasson, C. A. P. Qualidade no trabalho: estudo das condições de trabalho. Paraná: Coluna do Saber, 2004.

[12] Gaigher Filho, W.; Melo, S. I. L. LER/DORT: a psicossomatização no processo de surgimento e agravamento. São Paulo: LTr, 2001.

[13] Bernardes, J. M.; Renner, J. S Fatores de riscos para LER/DORT no setor de montagem de uma indústria de calçados. Fisioterapia Brasil, São Paulo, ano 10, n.13, maio/jun. 2009.

[14] Freitas, Fabiana Cristina Taubert de; Barbosa, Letícia Holtz. Análise de riscos biomecânicos presentes na atividade laboral de costureiras industriais. [2005?]. Disponível em: $<$ http://www2.rc.unesp.br/eventos/educacao fisica/biomeca nica2007/upload/258-1-A-CBB\%20-

\%20com\%20autores.pdf>. Acesso em: 20 abr. 2011

[15] Sá, F. D. de; Nascimento, Maria Adelaide A. do; Melo, Ana Carolline Carvalho de; Santos, Juliana da Costa; Adissi, Paulo José. Comparison of methods RULA and REBA for evaluation of postural stress in odontological services. In: International Conference on Production Research - Americas' Region 2006 (ICPR-AM06), Third, 2006, Curitiba, 2006. Disponível em:

$<$ http://moodle.ufsc.br/file.php/10364/comparison_of_meth ods rula and reba for evaluation of postural stress in 0 dontological services.pdf $>$ Acesso em: 02 mar. 2011.

[16] Mateus Junior, J. R. Estudo das ferramentas de avaliação física em ergonomia, equação NIOSH e RULA. 2009. $152 \mathrm{f}$. Dissertação (Mestrado em Engenharia de Produção) Programa de Pós Graduação em Engenharia de Produção da Universidade Federal de Santa Catarina, Florianópolis, 2009. Disponível em:

$<$ http://moodle.ufsc.br/file.php/10364/Estudo das Ferramen tas de avaliacao fisica_em ergonomia equacao_NIOSH_e

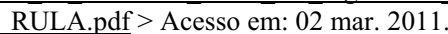

[17] Pavani, Ronildo Aparecido; Quelhas, Osvaldo Luiz Gonçalves. A avaliação dos riscos ergonômicos como ferramenta gerencial em saúde ocupacional. In: SIMPEP, XIII., Bauru, SP, 6 a 8 nov. 2006. Disponível em: $<$ http://www.simpep.feb.unesp.br/anais/anais_13/artigos/28 2.pdf $>$

Acesso em: 07 ago. 2011
[18] Lopes, P. R. Aplicação do ambiente simulado na resolução de problemas ergonômicos em postos de trabalho industrial. 2004. 122 f. Dissertação (Mestrado em Engenharia Mecânica) - Programa de Pós Graduação em Engenharia Mecânica da Universidade Federal do Paraná, Curitiba, 2004. Disponível em:

$<\underline{\text { http://moodle.ufsc.br/file.php/10364/Aplicacao do ambie }}$ nte_simulado_na_resolucao_de problemas_ergonomicos_e $\mathrm{m}$ postos de trabalho industrial.pdf $>$ Acesso em: $02 \mathrm{mar}$. 2011.

[19] Rudio, F. V. Introdução ao projeto de pesquisa. 30. ed. Petrópolis: Vozes, 2002.

[20] Gil, A. C. Como elaborar projetos de pesquisa. 4. ed. São Paulo: Atlas, 2002

[21] Marconi, M. A.; Lakatos, E. M. Fundamentos de metodologia científica. 6. ed. São Paulo: Atlas, 2008.

[22] RULA employee assessment worksheet. Based on: RULA: a survey method for the investigation of work-related upper limb disorders, McAtamney ; Corlett. Applied Ergonomics. 1993, 24(2), 91-99. Disponível em: $<$ http://moodle.ufsc.br/file.php/10364/RULA planilha.pdf $>$ Acesso em: 22 mar. 2011.

[23] BRASIL, Ministério da Saúde. Doenças relacionadas ao trabalho: manual de procedimentos para os serviços de saúde. Brasília, DF, 2001.

[24] Iida, Itiro. Ergonomia: projeto e produção. 2. ed. rev. e ampl. São Paulo: Edgar Blücher, 2005.

[25] Barbosa, Luís Guilherme. Fisioterapia preventiva nos distúrbios osteomuculares relacionados ao trabalho DORTs: a fisioterapia do trabalho aplicada. 2. ed. Rio de Janeiro: Guanabara Koogan, 2009. 